\title{
STRATEGI ASIAPR DALAM MEMPERKUAT HUBUNGAN MEDIA DENGAN FORUM WARTAWAN OTOMOTIF (FORWOT)
}

\author{
Fahrizal Gifari ${ }^{1}$ dan Hadi Purnama ${ }^{2}$ \\ ${ }^{1,2}$ Universitas Telkom
}

\begin{abstract}
ABSTRAK
Salah satu konsultan PR yang tengah berkembang di Jakarta adalah PT. Quantum Asia Corpora yang biasa disebut AsiaPR. AsiaPR adalah perusahaan yang bergerak di bidang Public Relations Consultant yakni sebagai penyedia jasa seorang public relations bagi perusahaan. AsiaPR juga telah banyak mengadakan kegiatan yang berhubungan dengan media Relations, seperti salah satunya adalah dengan para wartawan otomotif. Hal tersebut dikarenakan salah satu backbone AsiaPR adalah perusahaan otomotif seperti Toyota, Daihatsu, dan Suzuki. Produk otomotif tak jarang menggunakan press conference dalam setiap peluncuran produk baru yang dimiliki dikarenakan penyampaian promosi produk otomotif harus langsung disampaikan oleh orangorang yang mempunyai kredibilitas (informasi) tinggi. Oleh karena itu dibutuhkanlah para wartawan yang fokus pada bidang otomotif sebagai perantara perusahaan dengan konsumen. Penelitian ini bertujuan untuk mengetahui tujuan konsultan public relations AsiaPR membangun hubungan dengan media, strategi yang digunakan konsultan AsiaPR dalam membangun hubungan dengan Forwot serta manfaat yang didapat saat mempunyai hubungan kuat dengan media dan Forwot. Metode yang digunakan dalam penelitian ini yaitu metode kualitatif dengan pendekatan studi kasus untuk mengungkapkan kegiatan-kegiatan media Relations yang dilakukan AsiaPR. Pengumpulan data dilakukan dengan menggunakan in-depth interview, observasi, dan didukung data dokumentasi dari perusahaan. Penelitian ini menemukan tujuan dari media Relations yang dibangun konsultan AsiaPR untuk meningkatkan daya saing dan kemudahan mengakses media. Strategi yang digunakan dengan pendekatan personal antara konsultan dengan Forwot dan media secara langsung. Selain itu manfaat hubungan yang kuat dengan Forwot memberikan manfaat bagi AsiaPR dalam kegiatannya sebagai konsultan PR seperti tercapainya target media yang ditentukan klien.
\end{abstract}

Kata-kata Kunci: Public relations, strategi komunikasi, strategi media Relations, konsultan pr, jurnalis

\section{ASIAPR STRATEGY IN STRENGTHENING Media Relations WITH FORUM WARTAWAN OTOMOTIF (FORWOT)}

\begin{abstract}
One of the leading public relations Consultants in Jakarta is PT. Quantum Asia Corpora commonly called AsiaPR. AsiaPR is a company engaged in the field of Public Relations Consultant ie as a public relations service provider for companies. AsiaPR has also conducted many media Relations activities, such as with automotive journalists. This is because one of the backbone of AsiaPR is automotive company such as Toyota, Daihatsu, and Suzuki. Automotive products often use press conferences in every new product launches because the delivery of promotional automotive products must be directly delivered by people who have high Credibility (information). Therefore it takes journalists who focus on the automotive field as an intermediary company with consumers. This research aimed to find out the goal of AsiaPR Consultant in building the relation with Forum Wartawan Otomotif (Forwot) and the benefit they got in having a good relations with Forwot. The qualitative methods is used for this research in order to reveal the media Relations activities done by the AsiaPR. The data collection has done by in-depth interview, observation, and supported by data and documents from the company. This research find out the purpose from media Relations built by the AsiaPR Consultant to improve competitiveness and the simplicity in accessing data. The strategy used in personal approachment between AsiaPR with Forwot and the media directly. Moreover, the good relations with media give benefits for AsiaPR in their activities as the PR Consultant like the achievement of media target that selected by the client.
\end{abstract}

Keywords: Public relations, communication strategic, media Relations strategic, pr consultant, journalist

Korespondensi: Fahrizal Gifari, S.Ikom. Program Studi Ilmu Komunikasi, Fakultas Komunikasi dan Bisnis, Universitas Telkom, Jl. Telekomunikasi Terusan Buah Batu, Bandung 40257.Email: imfagi99@gmail.com 


\section{PENDAHULUAN}

Public relations (PR) atau yang di Indonesia sering disebut Hubungan Masyarakat (Humas) merupakan profesi dan organisasi yang tengah berkembang di masyarakat. PR adalah jembatan yang membangun relasi yang baik dengan publik PR itu sendiri. Pengertian tentang public relations yang dikemukakan oleh Frank Jefkins menyebutkan tentang bagaimana public relations memiliki keterkaitan dengan tujuan institusi. Public relations adalah semua bentuk komunikasi yang terencana, baik itu ke dalam maupun ke luar, antara suatu organisasi dengan semua khalayaknya dalam rangka mencapai tujuan-tujuan spesifik yang berlandaskan pada saling pengertian" (Jefkins dan Yadin, 2004: $10)$.

PR memiliki peran besar dalam bagian suatu perusahaan. Fungsi tersebut dimulai dari membantu organisasi membuat filosofi dan mencapai tujuan organisasi "...peran yang besar tersebut dimulai dari membantu membuat kebijakan dan rencana strategis, beradaptasi dengan lingkungan yang berubah, serta sukses bersaing dalam pasar saat ini" (Lattimore dkk., 2010: 14). Hal tersebut dapat terjadi dikarenakan public relations sering berinteraksi dengan publik organisasi sehingga memahami kebutuhan dan kepentingan dari masingmasing publik tersebut. Apabila dibandingkan dengan definisi public relations menurut Institute of Public relations, tujuan public relations lebih diperinci tidak hanya terbatas pada saling pengertian saja, melainkan juga berbagai macam tujuan khusus yang meliputi penanggulan masalah-masalah komunikasi yang memerlukan suatu perubahan tertentu misalnya mengubah sikap yang negatif menjadi positif.

Menurut Cutlip, Center dan Groom (2009: 321) public relations adalah bagian proses perubahan dan pemecahan masalah di organisasi yang dilakukan secara ilmiah, oleh sebab itu para praktisi public relations melakukan proses empat langkah untuk pemecahan masalah yaitu: (1) Fact-finding. Dalam tahapan ini, fact-finding atau mendefinisikan masalah mencakup dalam penyelidikan dan memantau pengetahuan, opini, sikap dan perilaku pihak-pihak yang terkait dengan, dipengaruhi oleh, tindakan, dan kebijakan organisasi. Pada dasarnya ini adalah fungsi intelijen organisasi. Fungsi ini menyediakan dasar untuk semua langkah dalam proses pemecahan masalah dengan menentukan “apa yang sedang terjadi saat ini?".

(2) Planning and Programming. Setelah para praktisi public relations menemukan masalah di dalam tahapan fact-finding, hal yang dilakukan selanjutnya adalah melakukan perencanaan dan pemrograman. Informasi yang dikumpulkan dalam langkah pertama digunakan untuk membuat keputusan tentang program publik, strategi tujuan, tindakan dan komunikasi, taktik, dan sasaran. Langkah ini akan mempertimbangkan temuan dari langkah dalam membuat kebijakan dan program organisasi. langkah kedua ini akan menjawab pertanyaan "Berdasarkan apa yang kita ketahui tentang situasi, apa yang harus kita lakukan atau apa yang harus kita ubah, dan apa yang harus kita katakan?". Pada perencanaan ini dikenal pula istilah perumusan $6 \mathrm{C}$, yaitu suatu penilaian terhadap hubungan komunikator dengan komunikan. Perumusan itu adalah: credibility, yaitu nilai kepercayaan publik terhadap pihak komunikator, context, yaitu faktor yang menghubungkan isi dari pesan dengan kenyataan pada lingkungannya, content, yaitu makna dan arti yang terdapat dalam pesan yang dapat dipahami oleh komunikan, clarity, yaitu faktor kesederhanaan dan kejelasan tidaknya pertentangan atau perbedaan dalam pesan, continuity dan consistency, yaitu faktor ada tidaknya pertentangan atau perbedaan dalam pesan, dan capability, yaitu faktor kemampuan untuk memberikan penjelasan.

(3) Komunikasi. Langkah ketiga adalah mengimplementasikan program aksi dan komunikasi yang didesain untuk mencapai tujuan spesifik untuk masing-masing publik dalam rangka mencapai tujuan program. Pertanyaan dalam langkah ini adalah "Siapa yang harus melakukan dan menyampaikannya, dan kapan, di mana, dan bagaimana caranya?" Tahapan ini juga disebut dengan tahapan penyampaian, jika penyampaiannya dilakukan secara berlainan maka dapat menimbulkan efek 
yang berlainan. Oleh sebab itu tahap ini sangat menentukan satu planning dan programming.

(4) Evaluation. Tahapan evaluasi ini merupakan tahap akhir dalam proses public relations ini, dengan cara melakukan penilaian atas persiapan, implementasi, dan hasil dari program. Penyesuaian akan dilakukan sembari program diimplementasikan, dan didasarkan pada evaluasi atas umpan balik tentang bagaimana program itu berhasil atau tidak.

Publik dalam praktik public relations dapat terbagi ke dalam dua bagian internal dan eksternal, hal itu didasari oleh masingmasing kepentingan penggunaan praktik public relations. Aktivitas terkait publik internal merupakan aktivitas PR yang berelasi dengan publik yang berada di dalam lingkungan organisasi. Contoh aktivitas terkait publik internal ini adalah relasi karyawan. Sedangkan aktivitas terkait publik eksternal merupakan aktivitas PR yang berelasi dengan publik di luar lingkungan organisasi. Contoh dari aktivitas terkait publik eksternal ini adalah relasi media (selanjutnya disebut media relations). Media relations sebagaimana didefinisikan oleh Jefkins lebih kepada cara mencapai publikasi pesan agar informasi dapat tersebar luas “... usaha untuk mencapai publikasi atau penyiaran yang maksimum atas suatu pesan atau informasi PR dalam rangka menciptakan pengetahuan dan pemahaman bagi khalayak dari organisasi atau perusahaan yang bersangkutan" (Jefkins dan Yadin 2004: 113).

Namun pada akhirnya tidak semua perusahaan memiliki departemen PR yang mampu menjalankan fungsi dan peran yang sesuai kebutuhan organisasi. Hal itu mendorong munculnya konsultan-konsultan bidang public relations sebagai pihak ketiga yang bertugas sebagai penjembatan antara organisasi dengan publiknya. Jefkins menjelaskan bahwakonsultan public relations terdiri dari orang-orang yang memang telah memiliki keahlian dalam bidang tersebut sebelumnya, "...penyelenggara jasajasa teknis dan kreatif tertentu oleh seorang atau sekelompok orang yang memiliki keahlian berdasarkan pengalaman serta latihan yang telah mereka dapatkan sebelumnya, dan dalam menjalankan fungsi-fungsi itu mereka memiliki suatu identitas perusahaan yang sah menurut hukum" (Jefkins dan Yadin 2004: 39).

Di Indonesia sendiri, berdirinya konsultan PR juga terus menjamur. Jika secara internasional ada PRCA (Public relations Consultants Associations), di Indonesia ada Perhimpunan Hubungan Masyarakat (Perhumas). Hal itu dikarenakan industri PR di Indonesia semakin berkembang pesat. Peluang jasa konsultan PR semakin banyak karena banyak perusahaan yang membutuhkan untuk menetapkan strategi komunikasi dan PR untuk menciptakan hubungan yang baik dengan publik. Sebuah artikel pada Daily Social id menyebutkan perkembangan industry public relations di Negara-negara Asia Pasific sendiri mengalami peningkatan yang pesat. World PR Report, Industri PR atau PR di Asia Pasifik jadi penyumbang terbesar dalam pertumbuhan industri PR dunia. Laporan ini dilansir oleh The Holmes Report dan the International Communications Consultancy Organization. Angka pertumbuhan yang diberikan Asia Pasifik adalah $13.6 \%$. Industri PR - humas - di dunia juga menunjukkan pertumbuhan, dengan angka sebesar $8 \%$ di tahun 2012, naik sedikit dari tahun, 2011 7.9\%, meski lebih rendah dari tahun 2010 (8.1\%). (Berlin, 2016)

Salah satu konsultan PR yang tengah berkembang di Jakarta adalah PT. Quantum Asia Corpora yang biasa disebut dengan AsiaPR. AsiaPR adalah perusahaan yang bergerak di bidang Public relations consultant yakni sebagai penyedia jasa seorang public relations bagi perusahaan. Seperti $P R$ strategic brand, $P R$ audit, corporate social responsibility, media management, $P R$ and media research, brand community, digital public relations, develop brand PR in-house system, crisis/issue management, dan capacity building. (AsiaPR 2013) AsiaPR juga telah banyak mengadakan kegiatan yang berhubungan dengan media relations, seperti salah satunya adalah dengan para wartawan otomotif. Hal tersebut dikarenakan salah satu backbone AsiaPR adalah perusahaan otomotif seperti Toyota, Daihatsu, dan Suzuki.

Produk otomotif tak jarang menggunakan pressconference dalam setiap peluncuran produk 
baru yang dimiliki. Hal tersebut dikarenakan penyampaian promosi produk otomotif harus langsung disampaikan oleh orang-orang yang mempunyai kredibilitas (informasi) tinggi. Oleh karena itu dibutuhkanlah para wartawan yang fokus pada bidang otomotif sebagai perantara perusahaan dengan konsumen. Oleh karena itu dibutuhkanlah para wartawan yang fokus pada bidang otomotif sebagai perantara perusahaan dengan konsumen (Forwot, 2005).

Sebagai konsultan PR, media relations dapat menjadi added value bagi konsultan agar lebih dipercaya oleh perusahaan untuk menggunakan jasa yang mereka sediakan. Media relations dapat membuka peluang kemitraan bagi para konsultan PR. Sehingga dalam persaingan antar konsultan, jika salah satu konsultan mempunyai media relations yang baik, maka akan menghasilkan competitive advantage bagi konsultan PR tersebut. Hal itu pula yang dilakukan oleh AsiaPR, melakukan pendekatan pada media agar dapat menciptakan kesan yang positif dalam hubungan antara konsultan dengan media. Bahkan kepada para anggotanya AsiaPR menekankan tentang cara bersikap yang baik kepada media atau yang biasa disebut dengan media handling, karena AsiaPR sadar bahwa media atau jurnalis menjadi elemen penting dari keberlangsungan perusahaan terutama berkaitan dengan reputasi perusahaan atau brand. Dengan melihat fenomena ini, penulis hendak mengangkat penelitian yang berjudul "Strategi Konsultan PR dalam memperkuat hubungan Media (Studi Kasus pada AsiaPR dalam kegiatan Media relations dengan Forum Wartawan Otomotif (Forwot)".

\section{METODE PENELITIAN}

Metode yang digunakan penulis dalam penelitian ini adalah menggunakan pendekatan kualitatif dengan menggunakan jenis penelitian studi kasus deskriptif. Menurut Bogdan dan Taylor dalam Pratama, dkk (2012) metode kualitatif dapat diartikan sebagai prosedur penelitian yang menghasilkan data deskriptif berupa kata-kata yang tertulis atau lisan dari orang-orang atau perilaku yang dapat diamati dan diarahkan pada latar dan individu secara utuh. Tujuan penelitian kualitatif adalah mencari dan memperoleh informasi yang mendalam dari banyaknya informasi. Dijelaskan oleh Kriyantono (2006: 65) "studi kasus adalah metode riset yang menggunakan berbagai sumber data yang bisa digunakan untuk meneliti, menguraikan, dan menjelaskan secara komprehensif berbagai aspek individu, kelompok, suatu program, organisasi atau peristiwa secara sistematis". Selain itu penelitian ini menggunakan paradigma konstruktivis. Strategi media relations, penelitian ini bertujuan untuk menjabarkan strategi media relations yang dilakukan oleh konsultan public relations PT. Quantum Asia Corpora (AsiaPR) terhadap Forum Wartawan Otomotif (FORWOT) dalam memperkuat media relations yang dimiliki sehingga nantinya dapat menjadi competitive advantage bagi AsiaPR sebagai perusahaan konsultan public relations.

\section{HASIL DAN PEMBAHASAN}

Hubungan media relations antara AsiaPR dengan Forwot tidak hanya berlangsung formal antara perusahaan dengan media, namun juga sudah bersifat business to people atau sudah mengenal bahkan secara personal anggota maupun staf didalamnya. Tak jarang personal masing-masing atau institusi saling bertemu untuk berdiskusi atau bertukar pola pikir dalam mempersiapkan suatu kegiatan dan sebagainya, hal itu disukai oleh para wartawan karena sifat wartawan yang ingin adanya pertemanan dalam proses kerja, bukan hanya melakukan pekerjaan atau memenuhi undangan yang diberikan dan putus sampai disitu.

Definisi strategi komunikasi oleh Rogers dalam Cangara (2014: 64) adalah suatu rancangan yang dibuat untuk mengubah tingkah laku manusia dalam skala yang lebih besar melalui transfer ide-ide baru. Hal tersebut berarti strategi komunikasi adalah sesuatu hal yang harus disiapkan untuk mengubah sesuatu sekaligus memperbesar ruang lingkupnya. Selain dari definisi tersebut tujuan daripada strategi komunikasi dijabarkan oleh R.Wayne Pace, Brent D. Peterson, dan M. Dallas Burnett dalam Zainal (2015: 115) bahwa tujuan sentral 
dari strategi komunikasi terdiri atas tiga, yaitu: (1) to secure understanding: artinya memastikan bahwa komunikan mengerti dengan pesan yang diterimanya; (2) to establish acceptance: yakni ketika komunika telah mengeri dan menerima, penerimanya itu harus dibina atau dijaga; dan (3) to motivate action: terakhir adalah bagaimana pesan yang diterima komunikan bisa memberikan motivasi kepada komunikan untuk melakukan action.

Strategipadahakikatnyaadalahperencanaan (planning) dan manajemen (management) untuk mencapai tujuan. Tetapi untuk mencapai tujuan tersebut, strategi tidak berfungsi sebagai peta jalan yang hanya menunjukan arah saja, melainkan harus menunjukkan bagaimana taktik operasionalnya (Lengkong, sondakh, \& Londa, 2017).

Frank Jefkins menjelaskan media relations sebagai "usaha untuk mencapai publikasi atau penyiaran yang maksimum atas suatu pesan atau informasi humas dalam rangka menciptakan pengetahuan dan pemahaman bagi khalayak dari organisasi atau perusahaan yang bersangkutan" (dalam Wardhani 2013: 9). Jefkins menjelaskan mengenai target media relations adalah pencapaian publikasi atau penyiaran maksimal atas informasi organisasi. Publikasi yang maksimal tidak hanya dari sisi jumlah media yang memuat, melainkan juga penyampaian informasi yang lengkap, serta berada di posisi yang strategis atau mudah dibaca, didengar atau ditonton oleh pemirsa. Definisi media relations menurut Phillip Lesly, 1991, merupakan sebagai hubungan dengan media komunikasi untuk melakukan publisitas atau merespons kepentingan media terhadap kepentingan perusahaan atau organisasi (Saputra dan Rulli, 2011: 129).

Menurut Public Relations Consultants Association (dalam Jefkins dan Yadin 2004: 39) Konsultan PR adalah:

"penyelenggara jasa-jasa teknis dan kreatif tertentu oleh seseorang atau sekelompok orang yang memiliki keahlian berdasarkan pengalaman serta latihan yang telah mereka dapatkan sebelumnya, dan dalam menjalankan fungsi-fungsi itu mereka memiliki suatu identitas perusahaan yang sah menurut hukum."
Sumirat dan Elvinaro menjelaskan (dalam Darmastuti 2012: 156-158) tentang strategi komunikasi public relations dengan media diantaranya adalah: (1) By serving the media. Strategi ini adalah strategi dengan memberikan pelayanan kepada media. Pada tataran ini, seorang public relations dituntut untuk memberikan pelayanannya kepada media dengan cara selalu siap dalam memberikan pelayanannya kepada media massa, sesuai yang dibutuhkan oleh media massa tersebut, (2) By cooperations in providing material. Strategi yang dilakukan dengan kerja sama yang baik dalam menyediakan bahan informasi. Yang terjadi penekanan dalam strategi ini adalah penghargaan yang tinggi dari seorang public relations kepada media, termasuk pekerja media. Seorang public relations dituntut untuk menghargai pekerja media dengan menyediakan waktu yant tepat dan menghargai kedatangan mereka, (3) By providing verivications facilities. Seorang public relations juga harus memikirkan fasilitas yang harus disediakan bagi pekerjapekerja media. Tujuannya adalah pekerja media merasa nyaman dalam bekerja, yaitu ketika mereka melakukan liputan terhadap perusahaan tempat public relations itu berada, dan (4) By building personal relationship with media. Strategi ini merupakan strategi yang dilakukan dengan membangun hubungan secara personal antara public relations dengan media massa (baik itu orang-orang yang ada di Institusi media maupun dengan wartawan pekerja media lainnya). Hubungan personal yang baik antara public relations dengan pekerja media diharapkan dapat digunakan sebagai dasar untuk membangun keterbukaan dan saling menghormati antarprofesi masing-masing.

Damastuti (2012) menjelaskan ada beberapa model yang dapat digunakan dalam membangun hubungan yang efektif dengan media. Model hubungan tersebut adalah model hubungan antara public relations dengan institusi media dan model hubungan antara seorang public relations dengan pekerja media.

Inti dari kegiatan humas public relations adalah melakukan komunikasi, baik yang ditujukan kepada internal maupun eksternal organisasi/ lembaga. Prinsip komunikasi yang 
efektif adalah, komunikator harus berorientasi kepada komunikan (Utomo, 2005).

Model hubungan antara public relations dengan institusi media adalah model yang bersifat bisnis. Hubungan dibangun dalam kondisi yang formal dan saling menguntungkan. Model hubungan ini disebut juga dengan model imbalanced commensalism relationship. Model Imbalanced Commensalism Relationship ini diambil dari kata "Komentalisme" yang artinya kondisi yang memungkinkan antara dua makhluk hidup yang hidup bersama tanpa saling merugikan antara satu dengan yang lain. Kata "imbalanced" sendiri menunjukkan bahwa efek yang diberika di antara keduanya tidak seimbang.

Model strategi PR dalam membangun hubungan dengan pekerja media (termasuk wartawan) adalah hubungan yang mengarah pada two-way symmetrical. Ini terlihat dari model hubungan yang informal, hubungan sebagai sahabat, hubungan simbiosis mutualisme, dan saling memercayai. Model ini bisa disebut dengan Model Harmonious Mutualisme Relationship, yaitu sebagai model gabungan antara model two-way symmetrical dan public information. Kata "harmonius" diambil dari kata harmony yang berarti adanya keselarasan antara PR dan pekerja media, juga dengan wartawan. Sedangkan "mutualisme" menunjukkan bahwa antara PR dengan pekerja media dan dengan wartawan mempunyai hubungan yang saling menguntungkan satu dengan yang lain.

Dari hasil wawancara didapatkan bahwa sebuah media dalam hal ini Forwot tidak ingin hanya diperlakukan sebatas pekerjaan saja, namun diperlukan adanya sifat pertemanan antar media dengan konsultan PR yang mengundang atau mempunyai kepentingan dengan media. Bisnis yang terjalin dalam media relations adalah bisnis kepercayaan, sehingga jika dialog antarpersonal tidak terjalin dengan baik maka media juga enggan untuk datang dan terlibat dan lebih mementingkan pekerjaan lain yang lebih penting. Hal tersebut yang beberapa konsultan PR lakukan, hanya fokus kepada pekerjaan dan melupakan sifat pertemanan antara wartawan atau media dengan konsultan PR.
AsiaPR menyadari bahwa hubungan kedekatan dengan media dapat membuat konsultan PR diprioritaskan dibanding kegiatan yang diadakan konsultan PR lain. Sehingga berdampak pada penting tidaknya suatu kegiatan yang diadakan oleh konsultan PR akan diukur oleh media berdasarkan kedekatan yang terjalin. Hal itu sesuai seperti pengertian dari public relations itu sendiri. Dikatakan oleh Byron Christian (dalam Nurjaman dan Umam, 2012: 105) bahwa public relations adalah usaha untuk mempengaruhi orang, guna berpikir baik terhadap suatu organisasi, menghargainya, dan mendukungnya. AsiaPR sebagai konsultan menyadari bahwa sebuah media dalam hal ini Forwot tidak ingin hanya diperlakukan sebatas pekerjaan saja, namun diperlukan adanya sifat pertemanan antar media dengan konsultan PR yang mengundang atau mempunyai kepentingan dengan media. Hal itu seperti yang dijelaskan oleh Nurudin (2008: 126) bahwa dalam membangun media relations kita harus menempatkan wartawan di atas segalanya dan itu secara psikologis akan membuat senang mereka. Wartawan akan merasa 'diorangkan', dihargai, dan dilayani dengan baik.

"Humas dan media merupakan mitra kerja yang saling menguntungkan, penting dan tidak terpisahkan. Media massa merupakan salah satu sarana untuk berkomunikasi atau menyampaikan suatu berita pada banyak orang dalam waktu yang singkat. Sehingga Humas media dan promosi merupakan elemen kegiatan komunikasi yang dilakukan perusahaan dalam rangka upaya meningkatkan penjualan jasa atau produksi” (Ardhoyo, 2013).

Dari hasil penelitian penulis pada tujuan AsiaPR mempunyai hubungan baik dengan Forwot, AsiaPR sudah mencapai tiga kategori tujuan media relations seperti yang dijelaskan oleh Iriantara (2011: 90) ketiga kategori yang tercapai yaitu: (1) Meningkatkan kesadaran. AsiaPR sebagai konsultan PR mendapatkan keuntungan saat memiliki hubungan dengan media yaitu dapat dikenal sebagai konsultan PR yang mampu memenuhi target yang diberikan oleh klien. Hal itu karena hubungan dengan media merupakan salah satu kelebihan yang 
dimiliki oleh AsiaPR. Sehingga AsiaPR bisa lebihbersaing dengan konsultan PRyanglainnya, (2) Mengubah sikap. AsiaPR sadar bahwa wartawan ingin untuk diperlakukan layaknya teman. Oleh karena itu AsiaPR melakukan pendekatan dengan personal atau bussines to people. Hal itu terbukti sampai dengan AsiaPR dianggap sebagai konsultan yang memiliki hubungan paling dekat dengan Forwot. Serta kerjasama yang terjalin juga sampai pada tahap baik, (3) Mendorong tindakan. Hubungan antara AsiaPR dengan Forwot yang sudah dekat membuat AsiaPR diminta untuk bekerja sama menyelenggarakan acara ulang tahun dari Forwot. Hal itu membuktikan hubungan yang timbal balik di antara kedua organisasi ini.

Setelah AsiaPR berhasil menjalin hubungan baik dengan media, cara untuk mempertahankannya adalah dengan menjalin komunikasi antara konsultan PR dan media. Seperti jika ada waktu dan kesempatan konsultan dengan media pergi minum kopi dan berdiskusi bersama untuk membahas suatu pekerjaan atau membahas hal lain di luar pekerjaan media. Hal itu seperti teori yang dijelaskan oleh Byron Chistian (Nurjaman dan Umam, 2012: 105) tentang public relations berguna untuk membuat seseorang berpikir baik terhadap suatu organisasi, menghargai dan mendukungnya.

Strategi yang digunakan AsiaPR dalam menjalankan kegiatan media relations dengan Forwot, yaitu: (a) Strategi pelayanan kepada media (By Serving the Media). AsiaPR sebagai konsultan PR melakukan upaya untuk melayani media dalam setiap kegiatan media relations yang dilakukan. Hal itu termasuk kepada strategi pelayanan media yang diberikan AsiaPR kepada Forwot dan media saat mengadakan suatu kegiatan secara formal ataupun secara non formal seperti saat diskusi dengan media, (b) Strategi dengan mempersiapkan fasilitas (By providing verivication facilities). AsiaPR dari hasil penelitian mencoba memberikan fasilitas dalam kegiatan media relations yang dilakukan, mulai dari media room sebagai ruangan media membuat berita dan sebagai ruangan untuk press launching. Hal itu merupakan upaya AsiaPR untuk memberikan fasilitas yang nyaman untuk media dalam hal ini termasuk Forwot dalam menjalankan pekerjaannya. Dalam kasus Forwot, AsiaPR menyiapkan acara Forwot dengan baik, salah satunya fasilitasfasilitas yang ada pada kegiatan, (c) Strategi hubungan personal dengan media (By building personal relationship with the media). Strategi ini yang digunakan AsiaPR dalam menjalin kedekatan dengan media. AsiaPR menjalin kedekatan pada Forwot secara personal dengan cara berdiskusi dan bersilaturahmi pada waktuwaktu tertentu seperti sebelum mengadakan kegiatan dan selepas kegiatan. Hubungan yang terjalin antara AsiaPR dengan Forwot bahkan sampai melibatkan personal-personal anggota bukan hanya dari institusi. Hal itu bertujuan agar membangun keterbukaan dan saling menghormati antarprofesi masing-masing.

Dijelaskan oleh Damastuti (2012: 163) bahwa untuk membangun hubungan yang efektif dengan media massa, ada dua buah strategi yang digambarkan dalam bentuk model, yaitu model imbalanced commensalism relationship dan model harmonius mutualisme relationship. Dalam model hubungan antara PR dengan institusi media seperti hasil wawancara dari supporting informant 1 bahwa ada hubungan bussines to bussiness yang dilakukan oleh AsiaPR terhadap Forwot dan media. Hubungan itu termasuk pada model pertama ini. Hal itu dikarenakan model ini adalah model hubungan formal antara public relations dengan media secara institusi. Keduanya melakukan kerjasama tanpa adanya yang dirugikan antar satu dengan yang lain. Namun AsiaPR dalam hubungan ini lebih diuntungkan dengan adanya relasi media yang kuat sebagai upaya meningkatkan kredibilitasnya sebagai perusahaan konsultan PR. Pendekatan yang dilakukan secara formal seperti mengirimkan ucapan selamat ulang tahun kepada media dan mengundang dalam acara media gathering.

Sedangkan mengenai model antara PR dengan pekerja media, hubungan kedua yang dijelaskan oleh supporting informant 1 people to people dan bussines to people masuk dalam model hubungan antara PR dengan pekerja media. Sifat dari model hubungan ini lebih kepada sifat pertemanan dan informal. Pada 
hubungan ini AsiaPR melakukan pendekatan secara personal pada wartawan, seperti mengirimkan ucapan ulang tahun, mengajak berdiskusi tentang suatu kegiatan, sampai meminta feedback sebagai bentuk evaluasi atas kegiatan yang telah berlangsung. Model inilah yang sering digunakan AsiaPR dalam memperkuat hubungan dengan media dalam hal ini Forwot. Hubungan ini pada akhirnya akan menciptakan simbiosis mutualisme untuk satu dengan yang lain, seperti AsiaPR yang membantu menyelenggarakan acara ulang tahun Forwot dan AsiaPR yang dibantu Forwot dalam kegiatan media relations yang diselenggarakan.

Model hubungan antara PR dengan pekerja media adalah model hubungan media relations yang paling sering digunakan AsiaPR dengan Forwot. Sifat dari model hubungan ini lebih kepada sifat pertemanan dan informal. Pada hubungan ini AsiaPR melakukan pendekatan secara personal pada wartawan, seperti mengirimkan ucapan ulang tahun, mengajak berdiskusi tentang suatu kegiatan, sampai meminta feedback sebagai bentuk evaluasi atas kegiatan yang telah berlangsung. Model inilah yang sering digunakan AsiaPR dalam memperkuat hubungan dengan media dalam hal ini Forwot. Hubungan ini pada akhirnya akan menciptakan simbiosis mutualisme untuk satu dengan yang lain, seperti AsiaPR yang membantu menyelenggarakan acara ulang tahun Forwot dan AsiaPR yang dibantu Forwot dalam kegiatan media relations yang diselenggarakan. Selain penerapan strategi pendekatan personal yang dilakukan AsiaPR. Strategi lain yang dilakukan adalah services media dengan menerapkan empat hal yang harus dipenuhi yaitu courtesy, clarity, accessibility, dan credibility.

AsiaPR masih belum mencapai bentuk komunikasi terencana dalam strategi media relations yang dilakukan, itu karena AsiaPR belum memiliki road map panduan strategi media relations. Sedangkan sebagai konsultan PR seharusnya sudah menyusun secara teknis kegiatan media relations, itulah alasan perusahaan menggunakan jasa konsultan PR. Seperti yang dijelaskan oleh Cutlip, Center dan Broom (2011: 83) konsultan PR menekankan pada pelayanan konseling dan perencanaan strategis, yang dianggap lebih profesional dibandingkan dengan taktik komunikasi yang diciptakan oleh agen pers dan agen publisitas.

Artis mengemukakan bahwa peranan public relations diharapkan menjadi mata dan telinga bagi top manajemen dari suatu organisasi atau lembaga. Ruang lingkup public relations adalah membina hubungan internal dan eksternal pada suatu perusahaan (Artis, 2011).

Ada beberapa manfaat yang diperoleh oleh perusahaan. Seperti yang dijelaskan Wardhani tentang definisi media relations (2013: 9) untuk menjalin pengertian dan hubungan baik dengan media massa dalam rangka pencapaian publikasi. Itu terbukti dengan AsiaPR menjadi mampu memenuhi target media yang ditentukan oleh klien saat mereka mempunyai hubungan yang kuat dengan media, terkhusus Forwot yang berperan dalam kegiatan otomotif karena jumlah anggota Forwot yang cukup banyak. Manfaat lainnya adalah mampu meningkatkan performance objective yaitu meningkatkan daya saing AsiaPR dengan konsultan PR lain yang ada di Indoensia. Seperti dijelaskan oleh Firsa Nova (2009: 52) tentang tujuan public relations merupakan kegiatan komunikasi untuk merepresentasikan citra perusahaan kepada publik. Publik dalam hal ini bisa berarti perusahaan yang nantinya berpotensi sebagai klien dari AsiaPR. Dengan performa yang dimiliki AsiaPR dalam media relations maka citra AsiaPR sebagai konsultan PR dapat meningkat.

Penulis menganalisis manfaat hubungan media relations AsiaPR dengan mengaitkan manfaat yang didapatkan dengan teori tentang tujuan public relations menurut Rosady Ruslan (dalam Nurjaman 2012: 113). Pertama, manfaat hubungan media relations AsiaPR ialah menumbuhkembangkan citra perusahaan yang positif untuk publik eksternal. Hubungan dengan Forwot mampu meningkatkan daya saing yang dimiliki AsiaPR terkait pemenuhan media dalam kegiatan yang diadakan menjadi citra positif yang dimiliki AsiaPR di depan perusahaan otomotif (ATPM). Sampai pada akhirnya salah satu perusahaan otomotif menggunakan jasa AsiaPR setelah melihat 
kinerja yang baik pada acara yang diadakan bersama Forwot. Manfaat juga di dapatkan oleh ATPM atau perusahaan otomotif dalam meningkatkan publisitas perusahaan. Seperti kegiatan press launching Ferarri yang dihadiri oleh lebih dari 80 media berdasarkan hasil penelitian, itu membuat publikasi produk dan perusahaan menjadi tersebar luas dan meningkatkan awareness dari perusahaan.

Kedua, manfaat hubungan media relations AsiaPR yaitu mendorong tercapainya saling pengertian antara publik sasaran dengan perusahaan. Kemudahaan dalam penerbitan press release oleh media, diskusi, bertukar pikiran, dan saling memberikan solusi terkait suatu kegiatan itu merupakan manfaat yang tercapai dengan memiliki hubungan yang kuat dengan media. Seperti dari hasil penelitian saat ada berita yang salah dari segi konten dapat dikonfirmasikan terlebih dahulu oleh pihak konsultan PR untuk meminta media membenarkan konten berita seharusnya.

Ketiga, manfaat hubungan media relations AsiaPR yaitu mengembangkan sinergi fungsi pemasaran dengan public relations. Manfaat juga didapatkan oleh media dan perusahaan yang menjadi klien dari AsiaPR. Seperti Forwot mendapatkan pemasukan seperti sponsor untuk kegiatannya dari ATPM yang pernah bekerjasama dengan AsiaPR, media juga mendapatkan pemasukan dari iklan perusahaan ATPM, berita-berita yang dimuat, display, dan advetorial. Di sisi lain perusahaan ATPM juga mendapat manfaat dengan peningkatan awareness produknya. Peningkatan awareness perusahaan didapatkan dari publisitas berita dari media-media otomotif. Dari anggota Forwot yang mencapai lebih dari 50 media berarti sudah ada 50 media otomotif yang memberitakan perusahaan tersebut.

Dari hasil penelitian juga penulis mendapatkan bahwa AsiaPR dalam membangun hubungan dengan Forwot tidak selalu mendapatkan manfaat. Ada beberapa hal yang menjadi kerugian yang didapatkan oleh AsiaPR saat membangun hubungan dengan Forwot. AsiaPR pada akhirnya melakukan dua pola saat harus berhubungan dengan media otomotif, pertama melalui Forwot untuk menjalin hubungan dengan media yang menjadi anggota Forwot, kedua langsung kepada institusi media. Dengan jumlah staf media handling yang hanya tiga orang hal tersebut mengakibatkan hubungan media relations memakan waktu lagi dalam prosesnya. Forwot hanya sebagai salah satu channel bagi AsiaPR untuk berhubungan dengan media, itu karena tidak semua media otomotif bergabung ke dalam Forwot. AsiaPR dalam mengirimkan undangan kegiatan media relations juga langsung dikirimkan kepada institusi media karena nantinya medialah yang menugaskan wartawan untuk meliput kegiatan. Oleh sebab itu Forwot hanya berperan sebagai komplementer bukanlah menjadi fasilitator penuh kegiatan media relations AsiaPR.

\section{SIMPULAN}

Setelah melakukan analisis dan interpretasi dari data hasil wawancara, observasi, dan data dokumentasi yang penulis dapatkan dalam melakukan penelitian ini, penulis membuat simpulan sesuai dengan tiga pokok permasalahan dan tujuan penelitian. Ketiga pokok permasalahan dan tujuan tersebut antara lain tujuan AsiaPR, strategi AsiaPR, dan manfaat AsiaPR mempunyai hubungan baik dengan media.

Tujuan AsiaPR mempunyai hubungan baik dengan media yaitu karena hal itu sangat penting untuk sebuah konsultan PR. Media merupakan kekuatan dalam layanan sebuah konsultan PR dalam memenuhi target permintaan dari klien, sehingga pada akhirnya bisa menjadi competitive advantages bagi perusahaan konsultan.

Strategi AsiaPR dalam memperkuat hubungan dengan Forwot diawali dengan pendekatan dengan media melalui intensitas bertemu terlebih dahulu menggunakan proses pendekatan personal. Model hubungan antara PR dengan pekerja media termasuk wartawan adalah model yang lebih sering digunakan AsiaPR dalam strategi pendekatannya. Strategi yang digunakan AsiaPR terbagi tiga yakni strategi pelayanan kepada media, strategi dengan mempersiapkan fasilitas, dan strategi hubungan personal dengan media. Strategi 
tersebut tidak lebih dahulu tertuang dalam road map media relations perusahaan, melainkan cara-caranya dibangun melalui pengetahuan manager atau staf yang sudah senior kepada juniornya berdasarkan pengalaman menangani media relations. Namun jika berkaitan dengan pekerjaan yang menyangkut klien strategi dibuat dalam bentuk proposal yang berisikan tujuan dan kegiatan media relations.

Manfaat AsiaPR mempunyai hubungan yang kuat dengan Forwot diantaranya adalah pertama konsultan menjadi mampu memenuhi target media yang telah ditentukan klien hal itu dikarenakan Forwot sebagai komplementer yang membantu menghubungkan AsiaPR dengan wartawan. Kedua, saat ada banyak kegiatan yang harus dihadiri media khususnya media otomotif, media akan memprioritaskan AsiaPR karena dianggap telah mempunyai kedekatan dengan mereka. Ketiga, saat ada kegiatan yang kurang begitu memiliki nilai berita bagi media, wartawan anggota Forwot tetap akan datang pada kegiatan yang diselenggarakan AsiaPR karena faktor kedekatan yang sudah terjalin.

Berdasarkan kesimpulan di atas maka peneliti memberikan saran untuk penelitian selanjutnya juga saran sebagai solusi bagi perusahaan. Peneliti menyarankan untuk peneliti lainnya untuk melakukan penelitian dengan melibatkan perusahaan yang merupakan pihak ketiga yaitu sebagai klien bagi konsultan dan sebagai pengiklan pada media untuk mencari tahu lebih mendalam keterkaitan antar ketiganya.

Peneliti memberi saran kepada perusahaan konsultan untuk memetakan prioritas media yang akan dibangun hubungannya. Hal itu bertujuan untuk mengefisiensikan anggaran yang digunakan pada kegiatan membangun hubungan dengan media dan wartawan.

Bagi akademis atau peneliti selanjutnya yang akan membahas strategi media relations konsultan PR peneliti sarankan dapat membahas bagaimana strategi yang dilakukan langsung kepada media secara langsung. Hal itu agar lebih menjelaskan tujuan hubungan media yang dibangun perusahaan konsultan.

\section{DAFTAR PUSTAKA}

Ardhoyo, T. (2013). Peran dan strategi humas (public relations) dalam mempromosikan produk perusahaan. Jurnal Ilmiah WIDYA, $15-21$

Artis. (2011). Strategi komunikasi public relations. Jurnal Sosial Budaya, Vol. 8, 184-197

AsiaPR. (2013). Company profile AsiaPR. Diakses dari http://asiapr.id/ companyprofile/\#page/1 5 Januari 2017

Berlin, M. (2016). Industri pr di asia pasifik tumbuh paling pesat. Diakses dari https:// dailysocial.id/post/industripr-di-asiapasifik-tumbuh-paling-pesat Pada 29 September 2016

Cangara, H. (2014). Perencanaan \& strategi komunikasi. Jakarta: Raja Grafindo Persada

Cutlip, M. S., dkk. (2007) Effective public relations, Terjemahan, Edisi Kesembilan, Jakarta: Kencana Prenada Media Group (2009). Effective public relations. Jakarta: Kencana Prenada Media Group

Damastuti, R. (2012). Media relations konsep, strategi \& aplikasi. Yogyakarta: Andi Offeset

Forwot. (2005). About forwot. Diakses dari https://forwot.wordpress.com/about/ Pada 5 Januari 2017

Iriantara, Y. (2011). Media relations konsep, pendekatan dan praktik. Bandung: Simbiosa Rekatama Media

Kriyantono, R. (2006). Teknik praktis riset komunikasi. Jakarta: Kencana Prenamedia Group

Lattimore dkk. (2010). Public relations profesi dan praktik. Jakarta: Salemba Humanika

Lengkong, S. L., Sondakh, M., \& Londa, J. (2017). Strategi public relations dalam pemulihan citra perusahaan (studi kasus rumah makan kawan baru megamas manado). Jurnal Acta Diurna, 2-11

Nova, F. (2009). Crisis public relations. Jakarta: Grasindo

Nurjaman \& Umam. (2012). Komunikasi dan public relations. Bandung: Pustaka Setia

Nurudin. (2008). Hubungan media konsep dan aplikasi. Jakarta: Raja Grafindo Persada

Pratama, Dkk. (2012). Strategi komunikasi dalam penyebaran informasi di pt chevron pasific indonesia. Jurnal Kajian Komunikasi. Unpad: Bandung 
Saputra, W \& Rulli, N. (2011). Public relations 2.0: Teori dan praktik public relations di era cyber. Depok: Gramata Publishing

Utomo, P. (2005). Strategi public relations dalam pelayanan informasi. Jurnal Komunikologi Vol. 2 No. 1, 32-40

Wardhani, D. (2013). Media relations sarana membangun reputasi organisasi. Jakarta: Graha Ilmu

Yadin, D. \& Jefkins, F. (2004). Public relations. Jakarta: Gramedia Pustaka Utama

Zainal, Y. A. (2015). Manajemen komunikasi filosofi, konsep, dan aplikasi. Bandung: Pustaka Setia 